\title{
The sustainability of public debt in Romania in economic and financial crisis
}

\author{
Marian Dobranschi, “Al.I.Cuza” University of Iasi, Romania
}

\begin{abstract}
Public finances are key driver in the EU for economic recovery as the debth of the recession and credit constraints require fiscal policy action.

This paper emphasis the needed review of public debt and its role in economic development as a particular challenge for emerging economies such as Romania. We explore the most important effects of public debt on economic growth like crowding-out effect, the realtionship between private and public financial transfers, the effect of public debt over GDP growth, inflation and on the sustainability of fiscal policy on the long run. Finnaly we estimate that the composition of public debt can suport debt stabilization and how debt management can stabilize the debt to GDP ratio in face to real returns and outputs growth and thus supports fiscal restraint in ensuring sustainability.
\end{abstract}

\section{Keywords}

External public debt, debt sustainability, economic growth, debt management, crowding out effect, budget deficit.

JEL Codes: H62, H63, H68

\section{Introduction}

Governments have to often borrow in order to finance expenditures on public goods and services that promote growth and increase nation's welfare. The decision of how much to borrow is that of fiscal policy which determines the targeted level of debt based on a sustainability analysis of government debt. One concept of sustainability relates to solvency, the ability of the government to service its debt obligations in perpetuity without explicit default, [6, p. 95]. Another concept put forth [6, p. 108] renders fiscal sustainability a broader scope by relating it to the government's ability to maintain its current policies while remaining solvent.

The growth of public debt has important implications for the economy. The growth of domestic debt leads to an increase in debt servicing costs, leaving less for investments in economic infrastructure and expenditures on such vital items as health, education and social security. The expansion of public borrowing can lead to the crowding out of private investments, especially when government borrows to cover current consumption spending and interest payments. Of course, it may not affect overall economic growth if government expenditure is mostly incurred on capital formation, such as the creation of infrastructure. Since the build-up of internal debt generally creates pressure on future inflation and an interest hike, in addition to the crowding-out effects, it may have an undesirable impact on the economy and society. An increase in fiscal deficits and public debt places negative pressure on financial systems and growth prospects, eroding a country's creditworthiness.

During the last 20 years, rising public debt has become a key issue in economic policy debates in many European countries, including Romania. The Stability and Growth Pact (SGP) and the Maastricht fiscal criteria for entry into the European Economic and Monetary 
Union (EMU) aimed at securing sustainable fiscal policies. More recently, however, it has turned out that the rules of the SGP could not be enforced, and that fiscal deficits have surpassed the 3\% of GDP limit in several EMU countries. Amendments to the SGP rules are being widely discussed and many observers question policy maker's determination to stick to sustainable fiscal policies.

Apart from the political debate about the SGP, the questions as to which fiscal policy is sustainable in the long run and whether policy makers are ready to succumb to sustainable fiscal policies are of interest. There is wide-spread agreement among economists about sustainability of public finances meaning that budgetary policy observes the long-term government budget constraint. According to this prescription, the sum of discounted future government budgetary surpluses must not be smaller than discounted future government debt including the initial stock of debt. The actual behavior of fiscal policy makers, on the other hand, is much less clear. In particular, to judge whether fiscal policies in a particular country were sustainable over a certain period of time, much information about past, present and future government budgetary policies is required, and assumptions about several parameters are necessary for most tests of this question.

A major reason why emerging economies are more prone to financial crises than mature economies is the atypical composition of their debt. Thus far, the literature has largely focused on external debt, notably on the inability of emerging economies to borrow in international capital markets in their domestic currency, which is sometimes coined the external dimension of "original sin".

\section{Evolution of public debt in post-socialist Romania}

At the beginning of the transition period in 1990, the public debt in Romania was insignificant. During the following years, the accumulation process accelerated. By 1998, the domestic public debt, together with the country's external debt, already increased to nearly $40 \%$ of Gross Domestic Product. Although the indebtedness degree of the country continues to be smaller than levels registered in other European countries, more dangerous is its accelerating trend in conditions of some not so very high-performing macroeconomic policy management. In order to adhere to NATO and European Union actions and agreements with international financing institutions, such as the International Monetary Fund and the World Bank, the problem of public debt and budgetary deficits has become more and more sharp. The major difficulties proceed from weak performance of the Romanian economy doubled by the complex problems of economic reform and restructuring, but also by more restricted access to external financing on international markets.

During the period after 1989, Romania faced more public debt accumulation as a new matter of macroeconomic policy, in contrast to other Central and East European countries such as Bulgaria, the Czech Republic, Hungary, or Poland. While the external debt of Romania was insignificant in 1990 (US\$230 million), the other Central and East European countries were already confronted with debt amounts of many billions of US dollars (Hungary - US $\$ 21.3$ billion, Bulgaria - US\$10.9 billion, Czech Republic - US\$4.4 billion). In the case of Poland, the figure was close to US\$50 billion. Eight years later, in 1998, the external debt of Romania already increased to more than 9 billion USD, while the other countries (with the exception of the Czech Republic, where external debt was five times larger than in 1990) registered either a modest growth (e.g. the case of Hungary with growth of US\$5.5 billion) or even a diminution (Poland with more than US $\$ 6$ billion, partially caused by cancellation of a proportion of its external debt, and in Bulgaria with US\$1 billion). One of the weakest performances of the Romanian economy after 1989 was the poor experience regarding the management of public debt and budget deficits.

In Romania, contrary to advanced countries, the external debt is the main component of total debt. However, in later years one can see that the accumulation of domestic public debt became a more important source to cover deficits. For instance, in 1998 it represented close 
to $8 \%$ of GDP. This evolution is in direct connection with efforts to improve the management of domestic debt, especially by enacting a new rule in April 1997 regarding the development of a secondary market for state obligations, restricting access to external sources of financing and taking over in public debt an important volume of non-efficient credits. For instance, the share of state loans approved by special normative documents evolved as follows: in $1992-8.1 \%$; in the 1993-1996 period- an average level of 5.7\% (with a maximum share of $11.7 \%$ in 1995); and in 1998-1999 - more than 30\% during an accelerating restructuring process of the banking system.

It is remarkable to see that Romania has also begun to demonstrate the correlation between election cycles and accumulation of public debt. According to this, when the leading political coalition has a large number of parties with various political orientations, as is the actual situation in Romania, then the budget policy loses its coherence and deficits will increase. On the contrary, in countries where the political power is in the hands of only one strong party, the chance to apply an efficient management of public debt is greater.

\section{Debt management role in ensuring its sustainability}

External debt management involves balancing resource mobilization and deployment as well as orderly repayment of future obligations. For sustainable debt management, policy makers need to project accurate debt dynamics that are sensitive to the way the current account deficits are being financed. If borrowed resources are not used productively, external borrowing can result in severe debt servicing difficulties. Debt management authorities therefore need to focus on efficient allocations of capital in sectors generating proper returns, and should effect monitoring to determine whether the borrowed resources are being used to improve the country's production capacity so that future obligations are serviced $[15, \mathrm{p}$. $112]$.

There is no rule of thumb for determining whether a country's debt level is sustainable. For an accurate projection on debt sustainability, several indicators should be assessed simultaneously in a forward-looking way. It should be noted, also, that debt sustainability analysis has to be country-specific, with consideration of the country's debt history, the level of sovereign ratings and the degree of development in the financial sector and capital markets. A country is said to have unsustainable debt if its level of debt has made its servicing projection (amortization as well as interest payments) incompatible with the projection of net capital inflows. Temporary liquidity problems can also make debt servicing difficult when they are triggered by a sharp drop in export earnings, an increase in interest rates, appreciation of the contracted currency, or increases in the price of imports, such as oil. The currency and interest rate composition of debt, its maturity structure and the availability of resources for debt repayments are all important factors that affect the vulnerability of the economy to external liquidity crises.

Debt sustainability analysis considers the indicators of "solvency" as well as "liquidity" together. This way of analysing debt sustainability resolves the issue whether a country needs to reduce its debt, as in the case of solvency, or to reschedule and restructure debt to make it sustainable. The common set of solvency indicators has been the ratio of external debt to exports, external debt to national income, debt service ratio and interest service ratio. The level of short-term debt has also been considered an important liquidity risk factor that can precipitate a foreign exchange crisis, especially when coupled with high or unsustainable current account deficits. Recent debt sustainability analysis takes into account the ratio of short-term debt to total outstanding debt and the ratio of international reserves to shortterm debt as common indicators of liquidity.

The trade deficit also reflects a macroeconomic disequilibrium. On the demand side of GDP growth, due to the higher rate of import volume increase than the export volume one, the negative contribution of net exports in 2006, for instance, cut almost half of the domestic demand, resulting a real GDP growth rate of 7.7 percent (see Table 1). From this point of 
view, the international trade is slowing the economic growth of Romania and if the domestic demand hadn't been driven by the final consumption (fuelled by the credit expansion) a much lower GDP growth rate could have been registered.

\section{Table 1 Evolution of GDP}

\begin{tabular}{|l|c|c|c|c|c|}
\hline Years & 2003 & 2004 & 2005 & 2006 & 2007 \\
\hline Real GDP growth & 5.2 & 8.5 & 4.1 & 7.7 & 6.5 \\
\hline Contribution of: & & & & & \\
\cline { 2 - 6 } Domestic demand & 8.8 & 12.9 & 8.7 & 14.1 & 12.3 \\
\hline Net exports & -3.6 & -4.5 & -4.5 & -6.4 & -5.4 \\
\hline
\end{tabular}

Source: Romanian National Commission for Prognosis

The macroeconomic costs of the persistent trade deficits are severely penalising Romania. The reversal of a high GDP growth rate of Romania, which is trying to match the development gap with EU during the process of economic and monetary convergence, is the worsening of its external balance. In our view, the trade and current account deficits are also revealing the Romania's lack of competitiveness, the limited resilience capability to the market forces pressure and the integration difficulties, not only in Europe but also at the global level. The energy intensity stands for the competitiveness factor with the most significant gap compared to other European countries. Moreover, the energy inputs, more and more expensive, spread through inefficient channels in the entire economy are seriously damaging the product competitiveness both on internal and external markets. The huge energy bill (including from imports, which amounted to EUR 5 billion in 2006, under the circumstances of higher world prices) is also a major contributor to trade deficit widening. The vicious circle of Romania's economic growth (see Figure 1), whose primary causes have been shown, is made up by a chain of vulnerabilities, starting from the obsolete economic structures (energy-intensive and material-intensive) which are creating an intrinsic dependency on imports, contributing to the rise of trade deficits and implicitly of current account deficits, whose coverage through progressive compensatory flows is going to increase the external debt. As a consequence, higher risks for the external balance sustainability occur, including for a financial turmoil, which could damage Romania's international position and its economic development. [8, p.94]

\section{Figure 1: The vicious circle of economic growth in Romania}




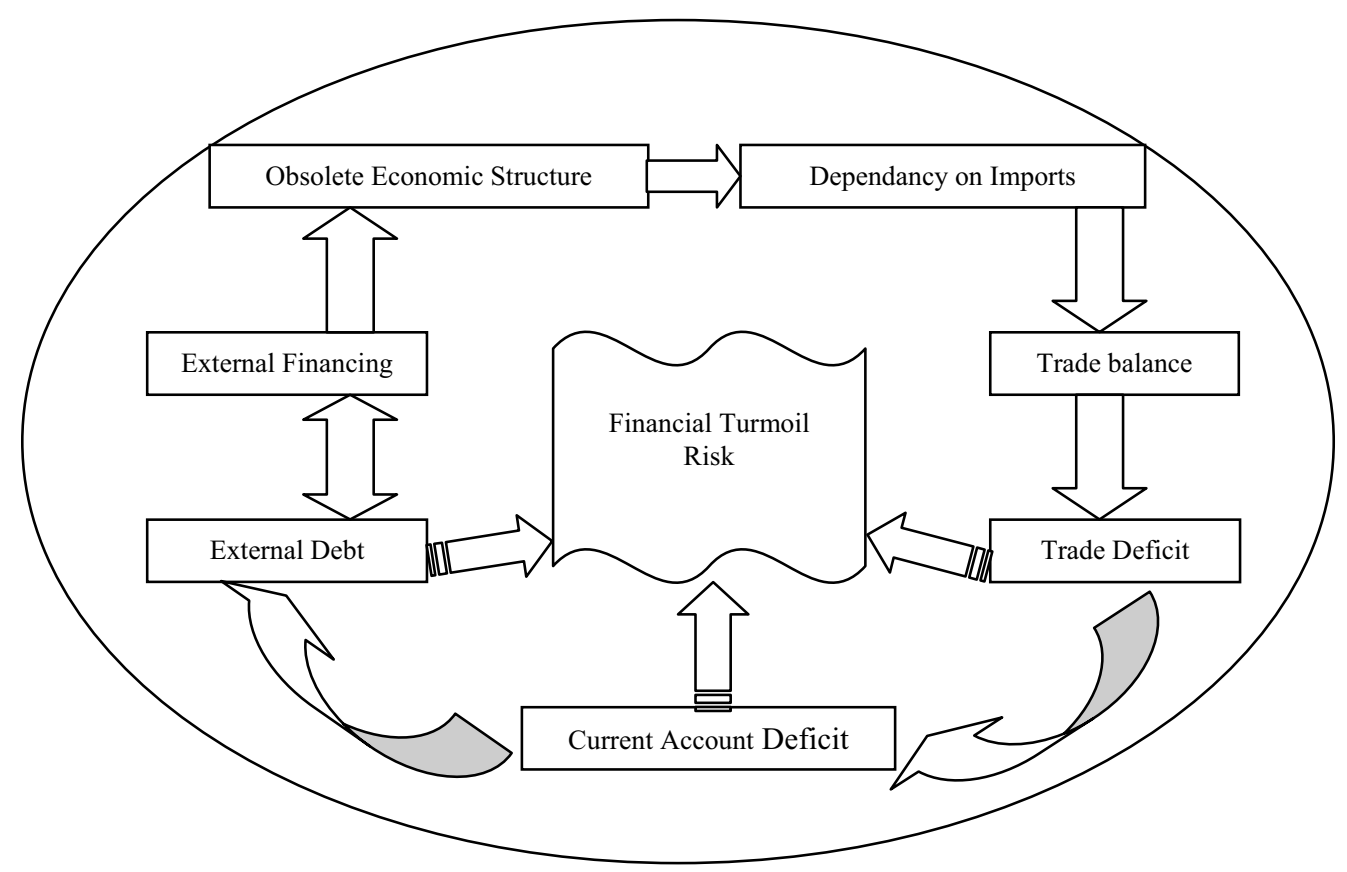

\section{The impact of public debt on economic development}

The conventional approach postulates a positive relationship between both the deficit and the inflation rate and the deficit and a negative current account, and no perceptible impact of the deficit on economic activity. Indeed, according to this theory, a rise in the deficit results in an additional supply of government bonds, which can only be sold by offering a more attractive yield, is creating upward pressure on interest rates. Consequently, the initial boost to the economy created by the deficit's impact on global demand ends up being partially diluted by the falloff in investment attributable to higher interest rates. This is called the "crowding out" effect. Also, the resurgence of demand draws in its wake an overheating of the economy, resulting in price increases. In the event that the deficit is monetized (printing money), the resulting fall in interest rates and increase in production will be very short lived, since the acceleration of inflation will drive these variables to their previous levels. In terms of foreign trade, the conventional theory postulates that a rise in the deficit, with its associated interest rate increases, stimulates an influx of foreign capital that must be compensated by a current account deficit owing to balance of payments identity. Consequently, all the elements are in place for the deficit to be an indicator of a macroeconomic management that is on the skids. Also, since the deficit drives inflation, it can only result in a depreciation of the national currency, according to the monetarist approach and the PPP model. It should also be noted here that the impact of inflation expectations on the exchange rate dominates that of the upward pressure on interest rates. Indeed, the deficit can result in negative real interest rates. The classic theories of budget deficit demonstrates its negative impact on economy (by reducing the national revenue) and living standard of the next generations that have to stand a higher fiscal pressure to pay the public debt. Engaging to budget expenditures higher than the current revenues is an imprudent policy with multiple effects. The increase of internal public debt as the effect of budget deficit financing from public loans may cause the bank interest increase with negative effects on investment credit demands and inflation [10, p.445]. 
Traditionalists argue that a reduction in the budget deficit will significantly help the economy in the long run. This theory is based on the following logic. When the government runs a budget deficit, it is spending more than it is taking in. In this way, national savings decreases. When national savings decreases, investment-the primary store of national savings-also decreases. Lower investment leads to lower longterm economic growth. Similarly, lower investment is accompanied by higher domestic interest rates, which decreases net exports. Based on this logic, a budget deficit is a drain on the long-term economy. Traditionalists argue that a reduction in the budget deficit will significantly help the economy in the long run.

This theory is based on the following logic. When the government runs a budget deficit, it is spending more than it is taking in. In this way, national savings decreases. When national savings decreases, investment-the primary store of national savings-also decreases. Lower investment leads to lower longterm economic growth. Similarly, lower investment is accompanied by higher domestic interest rates, which decreases net exports. Based on this logic, a budget deficit is a drain on the long-term economy. The present economic theory suggests that the reasonable public loans in a developing country do not alter the economic growth. If the lent resources are used in productive purposes, the repayment of the accumulated debts should be painless. In case of some high public debts there is risk regarding the country's repayment incapacity that might discourage investments and trouble the economic growth. The theory of excessive indebt was defined by Jeffrey Sachs who suggested that the payment owned to the creditors acts like a discouraging tax for production and that there is an indebt threshold beyond which any debt marginal increase generates a significant reduction of investments, a fact that reduces the future repayment capacity.

The mere existence of a budget deficit, meaning a higher amount of monetary resources in economy, generates inflation. If the budget deficit is covered by monetary issue, the impact on inflation will be even stronger. As the main objective of any central bank is to limit inflation, the monetary authorities will take measures to increase the reference interest that may attract speculative capitals, contributing to the national currency strengthen and consequently discouraging exports. Therefore another consequence of the budget deficit is the occurrence of current account deficit.

The modern theories of budget deficit consider that this unbalance does not have only inevitable negative effects. According to the "Ponzi gamble" theory, a less prosperous future is only a possible consequence of a period with high budget deficits. If the economic growth rate is higher that the debt rate, the budget deficits will be covered by the future economic growth from the general resources. This approach of the budget deficit means to study the average interest rate for the public debt and to compare it with the average economic growth rate. The rational game Ponzi in which repayments and debts are always replaced by a new debt was presented in the studies of Minsky (1982) and Kindleberger (1978). Applying the Ponzi game, the government may increase the living standard because each generation benefits by transfers and no generation pays additional taxes for them. But this point of view cannot be accepted because the budget deficit, even if it does not always lead to fiscal pressure increase, will determine lower investments as the savings will be mainly placed in governmental titles.

Despite Romania's classification by the World Bank in international statistics as a "less indebted" country, together with Poland, Croatia, the Slovak Republic, Czech Republic, Estonia, etc. (while Hungary is classified as "moderately indebted" and Bulgaria as "severely indebted"), some alarming signals were emitted by certain external financing institutions last year. With a background of continuing economic recession for the consecutive third year and a rapid external debt-service burden, certain international agencies specialised in evaluating country risk declassified Romania's score. One of the most important arguments was the worsening of sustainability indicators in correlation with other negative occurrences, such as diminishing accumulation resources, decreasing domestic savings and investment rates, and increasing risk for foreign investments. The fact that more than $90 \%$ of the gross country's 
debt is externally financed demonstrates the fragility of the national economy and the high degree to which it depends on external financing conditions for collecting new resources. In such conditions, the sustainability problem, already intensely preoccupying external financing institutions of Romania, should have to give serious incentives to those having an impact on macroeconomic policy decisions, especially to government.

\section{Conclusions}

The external vulnerability became an important issue as a result of recent financial crises. The debates focused on the external and public debt sustainability in order to identify the relationship between these two variables in order to investigate the degree of vulnerability of a country from the point of view of its international financial position and internal stability. So, the recent increase of external debt in Romania conduct to the necessity to investigate the debt sustainability for the external position and for the domestic debt. In theoretical and empirical studies on this issue are developed many techniques in order to analyze the debt sustainability regarding the existence and the type of sustainability, and the incidence of economic variables on debt sustainability. These variables can be used to influence the dynamics of public and external debt in order to ensure the intertemporal budget constraint. Starting with these methods we find that Romanian debt sustainability is weak and there are evidences for long term equilibrium between debt and current account.

Fiscal policy and government debt matter. First, looser budgetary policies crowd out private investment and lead to more foreign debt, a higher domestic interest rate and lower economic growth. Also, taxes on economic activity have adverse supply-side effects. Second, even if debt equivalence holds, higher public debt due to an intertemporal shift in taxation causes intragenerational inequity. In practice, heterogeneity among households (due to differences in age or number of children), liquidity constraints, uncertainty, precautionary saving, and distortionary taxes ensure that government debt affects real macroeconomic outcomes. Third, even if government debt and public consumption do not affect employment, output and growth, government debt smoothes intertemporal tax distortions and finances temporary rises in public spending or public investment projects with a market return. Fourth, unsustainable budget deficits matter because they may necessitate a switch from bond to money finance, leading to unpleasant monetarist and fiscal arithmetic. Alternatively, unsustainable budget deficits may cause explicit default. Fifth, without reputation or explicit binding contracts for the monetary authorities, the presence of long nominal government debt induces a higher equilibrium rate of inflation due to the danger of repudiation through unanticipated inflation. These time inconsistency problems can be partially overcome by appointing a conservative central banker, indexing public debt or issuing long debt in foreign currency.

It is desirable that governments impose a financial straitjacket. Most cabinets have many spending ministers and only one finance minister. To give more power to the minister of finance, norms are imposed on budgetary policies. Unfortunately most, including the Maastricht norms, are procyclical and give debt little role in smoothing intertemporal tax distortions and financing temporary increases in public spending. Furthermore, most norms apply to government debt rather than to net government liabilities. Governments should borrow for temporary increases in government spending and for net investment in projects with a market return, but the government should levy taxes for permanent increases in government spending and for losses on public investment projects, privatisation issues and operating foreign exchange reserves. In addition, governments may borrow for projects which yield a stream of services over a number of years. A high ratio of government debt to national income matters, since high taxation is needed to service debt. However, it is inadvisable to have a severe fiscal contraction (e.g. a temporary tax hike) to cut the ratio of government debt to national income.

Romania's financial stability and its country rating are also facing growing risks arising from the international environment: an abrupt correction of the current account global imbalance 
and the uncertainties related to the unpredictable monetary flows movements coming from the huge international reserves concentrated in Asia, mainly in China and Japan. In our opinion, Romania is constrained to take steps for preventing a fatal slipping from the sustainable development path and to reformulate its economic and monetary policies, aimed to maintain the external balance, giving priority to exports recovery and to attract foreign direct investments in area with clear comparative advantages.

\section{References}

1. Afonso Oscar, Alves Hernrique Rui, Vasconcelos B. Paulo, "Public deficits and economic growth”, Economic Modelling, April 2009, pp. 1102 - 1112;

2. Albu Lucian Liviu, Pelinescu Elena, "Sustainability of public debt and budget deficit", Economic policy, October 2000, pp. 3-22;

3. Becchiochi, Emmanuelle and Missali, Alessandro. „Managing Debt Stability”, Universita degli Studi di Milano, Dipartamiento di Economia Politice e Aziendale, www.economie.unimi.it, December 2004;

4. Bobeica Gabriel, Necula Ciprian, "Modeling the economic griwth in Romania.The influence of fiscal regimes", Institute of Economic Forecasting, June 2008;

5. Campeanu Emilia, Miricescu Emilian, "Analyzing the relationship between public and external debt sustainability: case study Romania", Empirica, June 2008, pp. 148 - 154;

6. Claeys Peter, "Policy mix and debt sustainability: evidence from fiscal policy rules", Empirica, 2008, pp. 89-112;

7. Georges Patrick. "Borrowing Short - or Long Term - Does the government really face a Trade-off”, Public Fianance Management, Vol. 6, Nr. 2,2005, pp. 206-243;

8. Georgescu George, "Current account deficit and implications on country risk of Romania", Institute of Economic Forecasting, October 2007, pp. 88 -97;

9. Kraay Aart and Nehru Vikram, "When is external debt sustainable”, The World Bank, February 2004;

10. Parvu Daniela, Clipici Emilia, "Budget deficit perspective in Romania", Empirica, April 2009, pp. 444 - 449;

11. Melecky, Martin. "A Cross-Country Analysis of Public Debt Management Strategies”, The World Bank, Banking and Debt Management Department, Policy Research Working Paper, Jyly 2007, pp. 30-37.

12. McFarlane, Lavern and Robinson, Wayne. "Public debt, money supply and inflation: a crosscountry study”, IMF Staff Papers, september 2009;

13. Panizz Ugo, "Domestic and external public debt in developing countries", United Nations Conference on Trade and Development, March 2008, pp. 1-26;

14. Panizz Ugo, "Domestic and external public debt in developing countries", United Nations Conference on Trade and Development, March 2008, pp. 1-26;

15. Staffs of the International Monetary Fund and the World Bank, "Amendments to the Guidelines for Public Debt Management", IMF, November 2003;

16. The World Bank Staff, "External debt and sustainable debt management", The World Bank, Washington 2004, pp. 108-121; 